\title{
APPEALABILITY OF 1404(a) ORDERS: MANDAMUS MISAPPLIED
}

By allowing actions to be transferred to a more convenient forum, section 1404(a) of the United States Judicial Code gives courts power to decide the place of trial when proper venue exists in more than one district. ${ }^{1}$ Prior to the enactment of section 1404(a), federal venue law alterations repeatedly shifted practical control over choice of forum between plaintiffs and defendants. ${ }^{2}$ Free exercise of this power was curtailed, however, by courts recognizing the fundamental importance of place of trial and the inevitable abuse of rules giving the choice to either party. The doctrine of forum non conveniens was invoked to dismiss actions brought in an inconvenient forum. ${ }^{3}$ But judicial application of forum non conveniens did not afford complete protection to the parties.

1. "For the convenience of parties and witnesses, in the interest of justice, a district court may transfer any civil action to any other district or division where it might have been brought." 28 U.S.C. \& 1404(a) (1952).

2. The Judiciary Act of 1789 gave plaintiffs free rein in choosing the place of trial: suit was proper wherever the defendant could be found. Judiciary Act of 1789, c. 20, $\$ 11$, 1 Stat. 78. This wide choice was later narrowed. Where federal jurisdiction was based solely on diversity, venue existed only in the districts of plaintiffs' or defendants' residence. In all other case's, the selection was made by Congress, plaintiffs being limited to defendants' residence. Act of Aug. 13, 1888, c. 866, § 1, 25 STat. 434. Under this act, corporate defendants able to choose their legal residence through incorporation achieved considerable power over venue. See Note, 49 Yale L.J. 724-29 (1940). To meet this problem, subsequent legislation giving private parties rights against corporations often included provisions allowing plaintiffs a greater choice of venue. E.g., Federal Employers' Liability Act, 36 StAT. 291 (1910), as amended, 45 U.S.C. $\$ 56$ (1952), amending 34 STAT. 232 (1906) ("district of the residence of the defendant, or in which the cause of action arose, or in which the defendant shall be doing business at the time of commencing such action"); Clayton Act, § 5, 38 STAT. 731 (1914), 15 U.S.C. $\$ 15$ (1952) ("district in which the defendant resides or is found or has an agent") ; 28 U.S.C. \$ 1401 (1952), amending 49 STAT. 1213 (1936) (stockholders' derivative suits: any district in which corporation could sue co-defendants). See United States v. National City Lines, 337 U.S. 78, 85 (1949) (collecting statutes with special venue provisions). More recently, a Supreme Court decision made corporations amenable to suit in the federal courts in any state in which they had appointed agents for service of process under state law. Neirbo Co. v. Bethlehem Shipbuilding Corp., 308 U.S. 165 (1939) (venue objections under these circumstances held waived); Comment, The Aftermath of the Neirbo Case, 42 ILL. L. REv. 780 (1948). Neirbo was codified and expanded in the 1948 Judicial Code. 28 U.S.C. \$ 1391 (c) (1952). See Barrett, Vente and Service of Process in the Federal Courts-Suggestions for Rcform, 7 VAND. L. REv. 608, 609-12 (1954). For an account of the development of venue requirements at common law, displaying the same basic conflict between the parties, see Ehrenzweig, The Transient Rule of Personal Jurisdiction: The "Power" Myth and Forum Conveniens, 65 Y ALE L.J. 289, 301 (1956).

3. Koster v. (American) Lumbermens Mut. Cas. Co., 330 U.S. 518 (1947) ; Gulf Oil Corp. v. Gilbert, 330 U.S. 501 (1947) ; see Braucher, The Inconvenient Federal Forum, 60 Harv. L. Rev. 908, 918-30 (1947) ; cf. Currie, Change of Veme and the Confict of Lazus, 22 U. Chr. L. Rev. 405, 416-38 (1955). 
Courts restricted the doctrine's application to extreme cases in limited areas, and dismissed plaintiffs often could not obtain a hearing in another forum. ${ }^{4}$ Section 1404(a) avoided these problems ${ }^{5}$ but gave rise to new questions. ${ }^{6}$ In removing the hardship of dismissal, authorization of transfer also eliminated

4. The plaintiff's choice of venue was not disturbed except in cases where extreme inconvenience to defendants was clearly shown. Gulf Oil Corp. v. Gilbert, supra note 3, at 508. And actions brought under special venue statutes were excluded. United States v. National City Lines, 334 U.S. 573 (1.948) (Sherman Act) ; Baltimore \& O.R.R. v. Kepner, 314 U.S. 44 (1941) (FELA). But see Koster v. (American) Lumbermens Mut. Cas. Co., supra note 3 (forum non conveniens does apply to stockholders' derivative stits).

Plaintiff, if economically able, was of course free to pursue his action in the convenient forum, or any other proper forum in which he could serve defendant, provided that the statute of limitations had not run and, if necessary, he could find property of the defendant to attach. See, e.g., Gore v. United States Steel Corp., 15 N.J. 301, 313-14, 104 A.2d 670, 677 (1954) (statute of limitations).

5. The substitution of transfer for dismissal mitigates the effect on plaintiff of a successful plea of inconvenient forum by defendant. The defendant is already before the court and need not be served again. Shapiro v. Bonanza Hotel Co., 185 F.2d 777, 779-80 (9th Cir. 1950). The pleadings and other pre-trial procedures already completed need not be repeated. Magnetic Engineering \& Mfg. Co. v. Dings Mfg. Co., 178 F.2d 866, 868 (2d Cir. 1950). And the statute of limitations tolls from the time the original action was brought. Jiffy Lubricator Co. v. Stewart-Warner Corp., 177 F.2d 360 (4th Cir. 1949), cert. denied, 338 U.S. 947 (1950). Moreover the plaintiff himself, in a proper case, may seek a transfer. Dufek v. Roux Distributing Co., 125 F. Sutpp. 716, 717-18 (S.D.N.Y. 1954). But the plaintiff is not the only party who may derive benefit from these changes. The lessened severity of the remedy has led to its increased availability. Thus the Supreme Court has held that the "judicial gloss" giving actions brought under statutes with special venue provisions immunity from forum non conveniens dismissal does not apply to 1404(a). United States v. National City Lines, 337 U.S. 78 (1949) (Sherman Act); Ex parte Collett, 337 U.S. 55 (1949) (FELA). And although no exact standards to guide the district courts in applying 1404(a) have been established, the strict standards of forum non conveniens have been held no longer controlling. Norwood v. Kirkpatrick, 349 U.S. 29 (1955); see Kaufman, Further Obscrvations on Transfers under Section 1404(a), 56 CoLum. L. Rev. 1, 1.1-12 (1956) (hereinafter cited as Kaufman, Further Observations).

6. For example, whether the law of the transferee or transferor forum applies is currently unclear. See Curry v. States Marine Corp., 118 F. Supp. 234 (S.D.N.Y. 1954). If the transferee district's law applies and the statute of limitations embraces a shorter period, a transfer may have the effect of old forum non conveniens dismissal. See Headrick v. Atchison, T. \& S.F. Ry., 182 F.2d 305 (10th Cir. 1950); Kaufman, Observations on Transfers under Section 1404(a) of the New Judicial Code, 10 F.R.D. 595, 600-01 (1951). A related question is the extent to which 1404(a) will be used to prevent shopping for a sympathetic forum. See Clayton v. Warlick, 232 F.2d 699 (4th Cir. 1956) (law of transferor circuit more favorable to plaintiff) ; Currie, supra note 3. See also Torres v. Walsh, 221 F.2d 319 (2d Cir.), cert. denied, 350 U.S. 836 (1955) (judgments in transferor district larger than in transferee district); Gibson, The Veme Clause and Transportation of Lazistits, is LAw \& ConteMr. Prob. 367 (1953). Equally far reaching is the practice, followed by some courts and rejected by others, of allowing plaintiffs to circumvent personal service requirements by transferring, over defendants' objection, to a district in which service would have been impossible, notwithstanding the existence of proper venue. Compare Foster-Milburn Co. v. Knight, 181 F.2d 949 (2d Cir. 1950), with Dufek v. Roux Distributing Co., 125 F. Supp. 716 (S.D.N.Y. 1954). 
the basis of appeal under forum non conveniens. ${ }^{7}$ And neither the legislative history nor section 1404(a) itself indicates whether Congress, while realizing the importance of a convenient forum to both parties, intended to allow or deny immediate review of transfer orders. ${ }^{8}$

Review of 1404(a) orders at the conclusion of an action does not adequately protect litigants. If a party can afford the increased expense caused by an erroneous transfer order, ultimate appeal offers him no opportunity to recoup. ${ }^{8}$ If such expense makes prosecution or defense of an action economically unfeasible, the resulting default or dismissal bars a hearing on the merits. ${ }^{10}$ Moreover, a party whose case has been prejudiced by his inability to require the personal appearance of a witness because of a 1404(a) order generally cannot show harmful error.11

7. Only the plaintiff could appeal under forum non conveniens. Dismissal furnished the ground for such appeal. Jiffy Lubricator Co. v. Stewart-Warner Corp., 177 F.2d 360, 362 (4th Cir. 1949), cert. denied, 338 U.S. 947 (1950) ; Braucher, supra note 3, at 937-38.

8. Section 1404(a) was introduced as part of a full-scale revision of the Judicial Code; accordingly, its legislative history is meager, consisting mainly of the Revisor's Note which make's no reference to appeal. It has, therefore, been argued that since evidence of intent to eliminate plaintiffs' forum non conveniens appeal is lacking, orders granting transfer should be reviewable. Magnetic Engineering \& M Mfg. Co. v. Dings Mfg. Co., 178 F.2d 866, 870 (2d Cir. 1950) (dissenting opinion). It might as easily be argued that no intention is shown to institute review where the motion is denied, and that, absent dismissal, no distinction between orders granting and denying transfer should be made.

Review will be used in this Note to refer to appellate consideration of a decision, by whatever means achieved, while appeal will be restricted to that review which a party may obtain as a matter of right.

9. For example, a patent suit is brought in state $A$, where an allegedly infringing article was sold. Defendant has its offices and laboratories in state $B$, plaintiff in state $C$. Defendant's motion to transfer to either state $B$ or state $C$, both on the west coast, from state $A$, on the east coast, is denied. The only issue in the action is highly technical, and defendant estimates that the cost of presenting its evidence in state $A$, taking into account disruptions in its operations caused by the absence of key personnel, will be $\$ 50,000$ more than in state $B$ or $C$. Although defendant wins a verdict, he cannot recover the additional $\$ 50,000$ expense. See Aircraft Marine Products, Inc. v. Burndy Engineering Co., 96 F. Sưpp. 588, 591-92 (S.D. Cal. 1951).

10. Thus, plaintiff, a citizen of state $A$, while traveling with a friend in state $B$, visits defendant's store and is injured by defendant's negligence. Defendant's motion to transfer the resulting suit from state $A$ to state $B$ is granted, since defendant has more witnesses, and its expenses for transporting witnesses would be greater than plaintiff's. Plaintiff cannot afford to go to state $B$ for trial, or to pay the expenses of her only witness, the friend who was with her when the accident happened. The suit is subsequently dismissed for want of prosecution. No appeal is available to the plaintiff. See Nicol v. Koscinski, 188 F.2d 537 (6th Cir. 1951); General Portland Cement Co. v. Perry, 204 F.2d 316, 318 (7th Cir. 1953).

11. See, e.g., Reade Shirts, Inc. v. Commonwealth Ins. Co., 102 F. Supp. 941 (S.D. N.Y. 1952) (plaintiff's key witness in suit on fire insurance policy refused to enter transferee district).

The deposition of a witness beyond the reach of process is admissible as satisfactory evidence of the facts to be proved. Fed. R. Civ. P. 26(d) (3); 5 Wigmore, Evidence 
Recognizing that immediate review would eliminate these difficulties but finding no basis for appeal as of right, many courts have resorted to the extraordinary writ of mandamus. ${ }^{12}$ Appellate courts are authorized to use mandamus only "in aid of their . . jurisdictions and agreeable to the usages and principles of law."13 Courts employing the writ have generally justified its application "in aid of their jurisdictions" as the only means of preventing frustration of their power to review 1404(a) orders, or "in accordance with the usages and principles of law" as a method of correcting erroneous refusals to exercise jurisdiction or abuses of discretion. ${ }^{14}$ However, if 1404(a) orders as a class can be brought within the mandamus power, ${ }^{15}$ so can many other

$\$ \S 1395-96,1401,1404(1940)$. To sustain his appeal in the situation depicted in text, appellant would presumably have to convince the court that he was prejudiced by losing the marginal benefit of personal testimony, and overcome the effect of similar arguments by his opponent that cross-examination at the trial would have neutralized whatever margin the court could divine.

12. The cases are collected in 6 Moore, Federal Practice $\llbracket$ 54.10[4], at 96-99 (1953) (hereinafter cited as MOORE); Kaufman, Further Observations, 1-11; Comment, Review of Section 1404(a) Federal Venue Proceedings by Extraordinary Writ, 43 CALIF. L. REv. 841 (1955).

13. "The Supreme Court and all courts established by Act of Congress may issue all writs necessary or appropriate in aid of their respective jurisdictions and agreeable to the usages and principles of law." 28 U.S.C. $\$ 1651$ (a) (1952).

14. E.g., Chicago, R.I. \& Pac. R.R. v. Igoe, 212 F.2d 378, 381 (7th Cir. 1954) (protecting jurisdiction to control lower courts) ; Paramount Pictures, Inc. v. Rodney, 186 F.2d 111, 116 (3d Cir. 1950), cert. denied, 340 U.S. 953 (1951) (compelling exercise of discretion by district court); Chicago, R.I. \& Pac. R.R. v. Igoe, 220 F.2d 299, 304 (7th Cir.), cert. denied, 350 U.S. 822 (1955) (abuse of discretion); Kaufman, Further Observations, 1-8.

Other justifications have been advanced. Thus the First Circuit, which is extremely hostile to review of $1404(\mathrm{a})$ orders, has based its power to issue the writ on transfer out of the circuit and hence out of its territorial jurisdiction. In re Josephson, 218 F.2d 174 (1st Cir. 1954). Judge Frank of the Second Circuit, on the other hand, indicated that he would issue the writ whenever necessary to further justice. Magnetic Engineering \& Mfg. Co. v. Dings Mfg. Co., 178 F.2d 866, 870-71 \& n.3 (2d Cir. 1950) (dissenting opinion). The background of mandamus is sufficiently uncertain to support either of these positions. See Notes, 63 Yale L.J. 105 (1953), 50 Colum. L. Rev. 1102 (1950). However, it is difficult to support use of mandamus when transfer is ordered to a district where venue is improper. For improper venue, if properly raised and preserved, is reversible error on appeal. Camp v. Gress, 250 U.S. 308, 316 (1919). Yet this very fact has been used to justify issuance of mandamus to prevent a trial that would, in the light of the fatal defect of venue, be useless. Indeed, this use of mandamus is the most common. Arrowhead Co. v. The Aimee Lykes, 193 F.2d 83, 85 (2d Cir. 1951) ; Foster-Milburn Co. v. Knight, 181. F.2d 949 (2d Cir. 1950) ; Kaufman, Further Observations, 1-2. Compare Bankers Life \& Cas. Co. v. Holland, 346 U.S. 379, 382 (1953) ; Gulf Research \& Development Co. v. Leahy, 193 F.2d 302 (3d Cir. 1951), aff'd by an equally divided Court, 344 U.S. 861 (1952) (rejecting mandamus in non-1404 (a) context where reversible venue error existed). See also note 23 infra.

15. The difference between those who consider mandamus the proper means of reviewing any 1404(a) order and those who would use the writ only where the individual case was extraordinary, regardless of the type of order, is illustrated by the opinions of the Second Circuit. Thus, in Arrowhead Co. v. The Aimee Lykes, supra note 14; Anthony v. Kaufman, 193 F.2d 85, 86 (2d Cir. 1951), cert. denied, 342 U.S. 955 (1952) ; Ford Motor 
classes of orders now denied immediate review. ${ }^{16}$ Other courts, opposed to judicial conversion of mandamus into a discretionary interlocutory appeal, have denied the writ in 1404(a) cases $;^{17}$ and the Supreme Court has not resolved the conflict. ${ }^{18}$

Although review of 1404 (a) orders by mandamus does threaten the policy barring interlocutory appeals, immediate review by other means would not con-

Co. v. Ryan, 182 F.2d 329 (2d Cir.), cert. denied, 340 U.S. 851 (1950) ; and Magnetic Engineering \& Mfg. Co. v. Dings Mfg. Co., supra note 14, mandamus was said to be the proper remedy, although no arguments were presented to show that the particular case was extraordinary. In these opinions, all by Judge Learned Hand or Judge Frank, the nature of 1404(a) orders as a class rather than the character of the particular case justified consideration of the writ. But in Torres v. Walsh, 221 F.2d 319 (2d Cir.), cert. denied, 350 U.S. 836 (1955), Judge Medina employed an entirely different approach. While agreeing that mandamus will always lie to keep the district court to its jurisdiction, he confined consideration of mandamus to correct discretion to cases established as extraordinary. It has been argued that Torres, concerning ordinary tort and contract claims, can be reconciled with the cases such as Ryan, involving large business enterprises, on the ground that large scale business litigation is in itself extraordinary enough to warrant interlocutory review, while small tort or contract claims are too trifling to deserve immediate attention of the appellate courts. Kaufman, Further Observations, 3-4. Adoption of this rationale would require reintroduction of the concept of jurisdictional amount into court of appeals procedure. In any event, a subsequent decision by Judge Hand demonstrates that the different approaches stem from a basic difference of opinion. In dismissing the appeal from a 1404(a) order in Littman v. Bache \& Co., 246 F.2d 490 (2d Cir. 1957), and inviting appellant to seek relief by mandamus, he mentioned no facts that transformed this ordinary contract diversity action into an extraordinary case.

16. Orders denying summary judgments, for example, are not appealable. Jones v. St. Paul Fire \& Marine Ins. Co., 108 F.2d 123 (5th Cir. 1939). Nor has any case been found using mandamus to review such a decision. Yet to be effective in protecting a party entitled to judgment from the expense of an unnecessary trial, just as in controlling a lower court, review must be immediate. Cf. Woods v. Robb, 171 F.2d 539, 541 (5th Cir. 1948). Furthermore, a district court with power under a correct view of the law to grant summary judgment, which, because of an error in understanding its authority, denied the motion, arguably has refused to exercise its jurisdiction. See Cohen v. Eleven W. 42nd Street, Inc., 115 F.2d 531 (2d Cir. 1940). Again, the element of discretion in denial of summary judgment motions facilitates utilization of an abuse of discretion rationale. See 6 MOORE $\llbracket 56.15[6]$. Moreover, when the substantive law is misconstrued by a district court, immediate review would clearly avoid a possibly expensive trial, although here the error could be corrected on appeal. While the courts of appeals might well decline to review such orders in the exercise of their discretion, the existence of relevant 1404(a) authority, coupled with occasional success, would provide a strong incentive to litigants desiring review or delay, and thereby subject the courts to the considerable burden of weeding out mandamus petitions. See note 31 infra and accompanying text.

17. E.g., Great No. Ry. v. Hyde, 238 F.2d 852 (8th Cir. 1956) ; Clayton v. Warlick, 232 F.2d 699 (4th Cir. 1956); In re Josephson, 218 F.2d 174 (1st Cir. 1954).

Although mandamus has, in a sense, always been a means of discretionary interlocutory review, it is limited to extraordinary cases and is not available merely because courts of appeals desire to protect litigants or to clarify the law. Compare Roche v. Evaporated Milk Ass'n, 319 U.S. 21 (1943), with Crick, The Final Judgment as a Basis for Appeal, 41 YALE L.J. 539, 564-65 (1932).

18. Norwood v. Kirkpatrick, 349 U.S. 29 (1.955) (no abuse of discretion; mandamus issue not reached) ; United States v. National City Lines, 337 U.S. 78 (1949) (no error below; mandamus issue not reached); Ex parte Collett, 337 U.S. 55 (1949) (same). 
tradict that policy and would, in fact, be consistent with recent Supreme Court decisions allowing appeal in closely analogous situations. The rule granting appeals only from final orders has been justified as protecting appellate courts and appellees from fragmentary and unnecessary appeals. ${ }^{19}$ Thus, in the line of cases stemming from Cohen v. Beneficial Industrial Loan Corp., the Supreme Court has held that orders will be regarded as final when they finally dispose of a substantial claimed right which is not an element of the cause of action and is so independent of it that joint review is neither necessary nor appropriate. ${ }^{20}$

19. Cobbledick v. United States, 309 U.S. 323, 324-26 (1940); 6 MOoRE ff 54.11. See Crick, supra note 17.

Appeals have been allowed from orders determining title and giving the right to immediate possession before the end of the action. Forgay v. Conrad, 47 U.S. (6 How.) 201 (1848) ; 6 MOORE If 54.13. And, in multi-party litigation, orders disposing of all the claims of one or more parties, where these claims were independent of those of the remaining parties have been held appealable. United States v. River Rouge Improvement Co., 269 U.S. 411, 413-14 (1926); see FEd. R. CIV. P. 54(b) ; 6 MOORE \ 54.15.

20. 337 U.S. 541 (1949); 6 MOore $\{54.14$. Defendant's motion to force plaintiff in a stockholder's derivative suit to post a bond demanded by state law had been denied on the ground that the bond was a procedural requirement and that general rather than local law applied. The Supreme Court, reversing on the substantive question, first held the order to be final and appealable. It noted, however, that had the application of New Jersey law been conceded, the controversy then concerning the amount of the bond, requisite finality would have been lacking, since the court by statute retained power to adjust the security during the proceedings. Cohen v. Beneficial Industrial Loan Corp., 337 U.S. 541, 547 (1919). A ruling requiring a bond would not have met the Cohen test, since the injury to plaintiff would not have been serious, and he would have the power, by refusing to comply and taking a dismissal, to make the order final. Compare Cohen v. Beneficial Industrial Loan Corp., supra, with Alexander v. United States, 201 U.S. 117 (1906) (order to produce papers before master not final), and Cushing v. Laird, 107 U.S. 69, 77 (1882) (order that garnishees pay fund into court not final while disposition of fund is still in issue).

In thus limiting the scope of his holding, Justice Jackson used language which might be construed as excluding orders involving discretion: "If the right were admitted or clear and the order involved only an exercise of discretion as to the amount of security, a matter the statute makes subject to reconsideration from time to time, appealability would present a different question." Cohen v. Beneficial Industrial Loan Corp., supra at 547. The complete irrelevance of discretion to the considerations of judicial efficiency and protection of litigants with which the Court was concerned, coupled with the fact that discretion is normally reviewable, see note 24 infra, indicates that continuing discretion was the subject of the language. Swift \& Co. v. Compania Colombiana Del Caribe, 339 U.S. 684 (1950), appeared to settle the question conclusively. The Supreme Court there held an order declining jurisdiction over one of two defendants and vacating an attachment, but not ending the action, to be final and appealable, despite a ruling by the circuit court that the order was discretionary. Swift \& Co. v. Compania Colombiana Del Caribe, 175 F.2d 513, 517 (5th Cir. 1949). After ruling on appealability, the Supreme Court held that a court's discretionary power to decline jurisdiction to protect itself from impositions could not in this case sustain the district judge's order. 339 U.S. at 688-89. Assuming without deciding that forum non conveniens, the other possible discretionary basis for the appealed order, applied to this type of case, the Court held that the district judge could not be sustained since he had not based his discretion on the proper factors, and that even if the consideration below had been so based, the order, on the facts of the case, still could not be sustained. Id. at 697-98. The discretion issue has returned. Compare the dictum in the majority opinion (order refusing to reduce allegedly excessive bail final and appealable "as there is no disr 
1404(a) orders meet all these tests. While such orders may be reopened, they are no more subject to continuous revision than the order in Colch itself. The questions presented by 1404 (a) motions concern convenience, the propriety of the proposed forum and the legal scope of the section. ${ }^{21}$ As such, they are rarely related to issues in the main cause of action.22 The difference between 1404(a) questions and the other issues in the action, by giving rise to different records, renders joint review unnecessary; and the difficulty of showing prejudice after trial usually makes such review impossible. ${ }^{23}$ Furthermore, as demonstrated by judicial reliance on mandamus, the right claimed under section 1404(a) is substantial. ${ }^{24}$ An erroneous order not only results in the increased expense and inconvenience that 1404(a) was designed to prevent, it may even change the outcome of the action. Nevertheless, the circuit courts

cretion to refuse to reduce excessive bail"), with the separate opinion of Justice Jackson (order appealable even though discretion is involved), in Stack v. Boyle, 342 U.S. 1, 6-7, 12-13 (1951). The Supreme Court has also used the Cohen definition to hold final an order denying an appeal in forma pauperis. Roberts v. United States Dist. Ct., 339 U.S. 844 (1950).

For collections of the types of orders appealable under Cohen, see 6 MOORE $\llbracket 54.14$; Underwood, Appeals in the Federal Practice from Collateral Orders, 36 VA. L. REv. 73136 (1950). Significantly, the collected decisions were not limited to allowing appeal in the particular case at hand but made entire classes of orders appealable.

21. 'See, e.g., Nicol v. Koscinski, 188 F.2d 537 (6th Cir. 1951) (balancing of conveniences) ; In re Josephson, 218 F.2d 174 (1st Cir. 1954) (propriety of proposed transferee forum) ; Chicago, R.I. \& Pac. R.R. v. Igoe, 212 F.2d 378, 382 (7th Cir. 1954), cert. denied, 350 U.S. 822 (1955) (1404(a) applies to cases removed from state courts).

22. Cases where the issue raised by the transfer order is directly connected with the principal cause of action would not be appealable. Thus Cohen would not apply to a denial of a transfer motion based on a prediction that the testimony of the witness for whose convenience transfer was sought would be excluded as irrelevant at trial. Cf. Libby, McNeill \& Libby v. Bristol City Line, 41 F. Supp. 386 (S.D.N.Y. 1941) (holding contract not rescinded essential to determination under forum non conveniens). See text at note 20 supra.

This requirement would also bar extension of the Cohen definition to cover other classes of orders, such as denials of summary judgments, where the interlocutory question was closely related to the issues in the main cause of action. See note 16 supra.

23. See notes 9-11 supra.

An order which transferred the action to a district where venue was improper would not be subject to immediate review, since a defect of venue, if not waived, is fatal, and thus review of the transfer order together with the final judgment would be appropriate. See note 14 supra. And where the transferring court, in its order, specified which state's law would apply, no appeal would lie against this part of the order, since prejudice arising from such an error could easily be shown in the ultimate appeal. Cf. Currie, supra note 3.

It may be argued that 1404(a) orders should not be appealable in any case where judgment for the appellant would moot the question. But under this criterion, the order in Cohen itself would not have been appealable since judgment for plaintiff would have mooted the security question. See note 20 supra.

24. While substantial is obviously a word of variable content, the decisions do give some guidance. Compare Stack v. Boyle, 342 U.S. 1 (1951) (refusal to reduce excessive bail appealable), with Assets Collecting Co. v. Barnes-King Development Co., 209 Fed. 206 (2d Cir. 1913) (order increasing security required of plaintiff not appealable). See also 6 MOORE $\{54.14$, at $139-40 \&$ n.25.

The argument might be made that since the disposition of a transfer motion is within 
have refused to allow immediate appeal; and the Supreme Court, in its decisions on 1404 (a), has avoided the question of review, leaving the conflict with Cohen unresolved. ${ }^{25}$

Although courts have buttressed their refusal to allow immediate appeal with arguments that granting review as of right fosters delay and encourages frivolous appeals, ${ }^{26}$ review by mandamus is equally subject to these criticisms. ${ }^{27}$

the discretion of the district court, no "right" to a particular forum exists. But a district judge whose decision is based on an error in interpreting the statute or on an abuse of discretion will be reversed when means of reviewing the de'cision can be found. See cases cited note 14 supra; Kaufman, Further Observations, 1-2, 11. And appellate courts may review the discretion of lower courts on appeal as well as by extraordinary writs. Thus, while injunctions are within the discretion of the district court, Petroleum Exploration, Inc. v. Public Serv. Comm'n, 304 U.S. 209, 218 (1938), an immediate interlocutory appeal is given from any order granting or denying an injunction, 28 U.S.C. $\S 1292$ (1952). Similarly, though mandamus is within the discretion of the issuing court, this discretion is subject to review. Ex parte Republic of Peru, 318 U.S. 578, 584-85 (1943) (dictum).

25. Littman v. Bache \& Co., 246 F.2d 490 (2d Cir. 1957) (holding 1404(a) orders unappealable and collecting cases); Kaufman, Further Observations, 1 \& n.3 (collecting cases).

None of the Supreme Court decisions have involved review of the dismissal of an appeal. See note 18 supra.

26. All States Freight, Inc. v. Modarelli, 196 F.2d 1010, 1012 (3d Cir. 1952) ; Clinton Foods, Inc. v. United States, 188 F.2d 289, 291-92 \& n.1 (4th Cir. 1951); see note 25 supra.

27. Mandamus is generally treated as a motion before the circuit court and therefore is immune from the possible delays of the thirty day period for filing appeals, FED. R. CIv. P. 73(a), and the forty day period for docketing appeals, FED. R. CIv. P. 73(g), 75(j). The writ may also be considered out of turn. See, e.g., 3D CIr. Rule 19; 4TH CIR. RULE 31. Nevertheless, as shown by the table below, petitions for mandamus in fact are not necessarily reached sooner than appeals.

Average time (in months) required to dispose of petitions for mandamus to review 1404 (a) orders where no appeal was concurrently filed, and median time (in months) from notice of appeal to disposition of cases during fiscal year ending June 30,1955 :

\begin{tabular}{lccc}
\hline \hline Circtit & $\begin{array}{c}\text { Number of } \\
\text { mandamus } \\
\text { cases }\end{array}$ & $\begin{array}{c}\text { Average time } \\
\text { on mandamus }\end{array}$ & $\begin{array}{c}\text { Median time } \\
\text { on appeal }\end{array}$ \\
\hline D.C. & 1 & 3.3 & 10.5 \\
1st & 1 & 6.3 & 6.4 \\
2d & 2 & 1.7 & 8.0 \\
3d & 2 & 6.3 & 6.3 \\
4th & 1 & 5.9 & 4.8 \\
5th & 1 & 0.7 & 10.0 \\
6th & 3 & 0.3 & 8.1 .8 \\
7th & 5 & 5.6 & 7.9 \\
8th & 1 & 2.1 & \\
9th & none & & \\
10th & none & & \\
\hline
\end{tabular}

Mandamus figures based on letters from the Clerks of the United States Courts of Appeals to the Yale Law Joumal, on file in Yale Law Library. Appeal figures derived from DIR. Admin. Off. U.S. Crs. Ann. Rep. 159 (1955). 
For example, just as appeal entails stay of the appealed order, ${ }^{28}$ a stay is invariably granted when courts employ mandamus to review 1404(a) rulings. ${ }^{20}$ Similarly, the discretionary use of mandamus need not result in practical review of a lesser number of cases than would appeal granted as of right. Once a court accepts mandamus as the ordinary mode of review for 1404(a) rulings, it must examine the merits of each petition to determine if the writ will issue. Further, since the primary reason for review in these cases is to protect individual litigants rather than to settle issues of law, ${ }^{30}$ correction of error cannot be postponed to a more convenient time as in review by certiorari. ${ }^{31}$ Nor are 1404(a) orders the type of ruling in which determination of the possibility of error can be removed from the actual discovery of error. ${ }^{32}$ And the scope of review on appeal need not be any different from that on mandamus. ${ }^{33}$ Thus

28. FED. R. Crv. P. 62(a), 73(d) (automatic stay for ten days; stay pending appeal on filing supersedeas bond). No such provision exists for a stay upon filing of petition for mandamus.

The rules provide thirty days for filing a notice of appeal. Id. at 73 (a). But if appeal of 1404(a) orders were allowed, delay in filing an appeal from an order granting a transfer beyond the automatic stay of ten days might be unwise since once the papers had been transferred, the appeal could be barred. See Magnetic Engineering \& Mfg. Co. v. Dings Mfg. Co., 178 F.2d 866, 867-68 (2d Cir. 1950).

29. See, e.g., Littman v. Bache \& Co., 246 F.2d 490 (2d Cir. 1957) (stay continued by court of appeals to allow filing of petition for mandamus); Magnetic Engineering \& Mfg. Co. v. Dings Mfg. Co., supra note 28, at 867-68 (appeal treated as petition for mandamus to avoid effect of papers having been transferred). In many cases the papers are retained pending mandamus even though a formal stay is not granted. In re Josephson, 218 F.2d 174, 177 (1st Cir. 1954); Hart \& Wechsler, The Federal Courts and the Federal System 981 n.8 (1953).

30. See note 14 stipra. But see Norwood v. Kirkpatrick, 349 U.S. 29, $42-43$ (1955) (dissenting opinion; importance of settiing law).

31. The Supreme Court will deny certiorari on the ground that the issues presented are of interest only to the parties and not to the public, Rice v. Sioux City Memorial Park Cemetery, Inc., 349 U.S. 70, 74 (1955), or because the public issue is not propitiously presented by the particular case, Maryland v. Baltimore Radio Show, Inc., 338 U.S. 912, 918 (1950) (dictum). While this policy may be justified by considerations of efficiency, the same considerations do not apply to the courts of appeals where no previous review has occurred, where added business can be countered with added judges and where the statutory basis for certiorari does not exist. Compare 28 U.S.C. $\$ \$ 1254(1), 1255(1), 1256$, 1257 (3) (1952), with 28 U.S.C. $\$ \$ 1291-93$ (1952). See HART \& WeCHSLER, The FedERAI. Courts and the Federal. System 1402, 1404-05 (1953).

32. When, however, the lack of merit in the challenge to the transfer order is obvious, the matter can be handled as expeditiously on a motion to dismiss an appeal as by mandamus. Jiffy Lubricator Co. v. Stewart-Warner Corp., 177 F.2d 360, 362-63 (4th Cir. 1949), cert. denied, 338 U.S. 947 (1950); MoMillan v. Taylor, 160 F.2d 217, 219 (D.C. Cir. 1946) (dismissing appeal) ; 1st. Cm. Rule 26(3); 2D Cir. Rule 11(d) ; 4TH Cir. Rule 9(3); 6TH Cir. Rule 15(3); 7 Th Cir. Rule 12(g); 10 Th Cir. Rule 14(4) (all providing speedier procedures for appeals to be heard on motion to dismiss).

33. Jiffy Lubricator Co. v. Stewart-Warner Corp., supra note 32, at 362-63. The standard most likely to result in reasonable appellate policy on 1404(a) orders would be to treat determinations of convenience vel non as findings of fact, reversible only if clearly erroneous, FED. R. Crv. P. 52(a); assessments of relative conveniences and the interests of justice as questions within the discretion of the district judge, reversible only for abuse, 
knowing that consideration of the merits will result, litigants are unlikely to be deterred from seeking relief by the necessity of filing a petition rather than a notice of appeal. ${ }^{34}$

Whether immediate review is desirable would therefore seem to be the real issue. Review of any ruling may postpone ultimate disposition. Properly administered, review of 1404 (a) orders would present few possibilities of delay. ${ }^{35}$ Transfer motions normally are made at a very early stage of a proceeding. ${ }^{36}$

see Bridoux v. Eastern Air Lines, Inc., 214 F.2d 207 (D.C. Cir.), cert. denied, 348 U.S. \$21 (1954); and decisions on the legal scope of 1404 (a) and related problems as conclusions of law, reversible for error, cf. Great Atl. \& Pac. Tea Co. v. Supermarket Equipment Corp., 340 U.S. 147 (1950). These standards are equally possible under appeal and mandamus.

34. While the use of a discretionary writ allows a court to discourage litigants from seeking review, discretion does not guarantee this result. The essential element is a policy of denying review without considering the merits. Compare In re Josephson, 218 F.2d 174, 183 (1st Cir. 1954) (only First Circuit case where review of 1404(a) order was attempted), with Second Circuit cases cited note 15 stpra. But if the stakes are high enough, even a stringent policy of selecting cases for review will not prevent the filing of unwarranted petitions. Thus, despite the rigorous standards of the Supreme Court in dealing with certiorari and even though review on the merits was granted in less than $20 \%$ of the certiorari cases considered during the period 1945-54 (including petitions for certiorari in forma pauperis), the number of certiorari petitions has not shown an appreciable decline. Nor did a denial rate of at least $95 \%$ result in a decrease in the number of petitions for certiorari in forma pauperis. DIR. Anmrn. Off. U.S. CTs. ANn. Rep. 149-50 (1955).

35. Courts can mitigate the delaying effects of appeal by several means other than denial of review. Thus, a policy of promptly transferring the papers ten days after the transfer is granted will limit the time for filing notice of appeal. See note 28 supra. Furthermore, a policy of dealing with frivolous appeals on motion to dismiss will considerably expedite their disposition. See note 32 supra. Frivolous appeals can be further discouraged by the imposition of damages on the party wasting the time and money of the public and the appellee. While damages for frivolous appeals are not common, they are authorized by law and approved by the cases. 28 U.S.C. $\$ 1912$ (1952) ; Slaker v. O'Connor, 278 U.S. 188 (1929) ( $\$ 150$ plus costs); In re Midland United Co., 141 F.2d 692 (3d Cir. 1944) ( $\$ 1,000$ to appellees for counsel fees); see Mason v. Summer Lake Irrigation Dist., 216 F.2d 609 (9th Cir. 1954), cert. denied, 348 U.S. 937 (1955) (penalty not imposed because section had fallen into disuse, but warning served for future cases). See also 28 U.S.C. $\$ 1927$ (1952) (counsel may be personally liable for statutory costs arising from his multiplication of the proceedings).

36. While 1404(a) is silent as to when the motion should be made, the conditions requiring transfer would ordinarily be known early in the action, and failure to move at that time might well be regarded as requiring denial of the eventual motion in the interest of justice. Adler v. McKee, 92 F. Supp. 613 (S.D.N.Y. 1950); Nagle v. Pennsylvania R.R., 89 F. Supp. 822 (N.D. Ohio 1950).

If appeal as of right were allowed, a party not really inconvenienced might be tempted to make a transfer motion late in the proceeding in order to gain the benefit of the increased delay. An appeal from the denial of such a groundless motion would be particularly subject to a motion to dismiss for failure to present a substantial question. See note 32 supra. If a more certain solution to the problem of timing transfer motions is desired, the statute or the Federal Rules might be amended to allow untimely motions only by leave of the court. See Braucher, The Inconvenient Federal Fornm, 60 HARv. L. REv. 908, 93839 (1947). 
Appeal of an order determining a transfer motion would bar neither completion of the pleadings and discovery, nor consideration of pre-trial motions not requiring the presence of witnesses whose convenience is in issue, nor even entry of the action on the trial docket in the original district. ${ }^{37}$ In cases in-

37. Conceptually, an order final under Cohen is not issued in the main cause of action but in a separate collateral action. Therefore, stay operates only to halt further steps in the collateral action, and not, except where the collateral and main actions coincide, in the main action. The conceptual problem raised by the notion that removing the record from the district court leaves it without jurisdiction during the appeal can thus be answered by the equally conceptual argument that the collateral action has its own record and that only this record is removed by the appeal. Cf. Magnetic Engineering \& Mfg. Co. v. Dings Mfg. Co., 178 F.2d 866, 867-68 (2d Cir. 1950); Crick, supra note 17, at 541-44.

A somewhat analogous situation exists when an appeal is taken from an interlocutory order under 28 U.S.C. $\$ 1292$ (1952). Such an appeal brings before the reviewing court as much of the record as is required for considering the merits of the interlocutory order, Ex parte National Enameling \& Stamping Co., 201 U.S. 156 (1906), but leaves the court below with jurisdiction to continue its proceedings in the action, Foote v. Parsons NonSkid Co., 196 Fed. 951 (6th Cir. 1912) (case may be settled in court below while interlocutory appeal is pending); Sutherland Paper Co. v. Michigan Carton Co., 14 F.2d 700 (E.D. Mich. 1926) (dictum; bill may be amended during pendency of interlocutory appeal). In these cases, a stay is not a matter of right-though the appeal is. This factor does not affect the theoretical question whether the same action can be before two courts at the same time. Ex parte National Enameling \& Stamping Co., supra at 161 (then existing law on issuance of stay) ; FED. R. Crv. P. 62(a) (present rule on stay of interlocutory orders). See also Note, 65 YaLE L.J. 708, 709 (1956).

On a more realistic level, neither protection of the appellant nor preservation of the appellate court's jurisdiction requires the stay of those proceedings not called into question by the order. For example, a party will not be seriously injured by being required to take depositions for discovery pending appeal since depositions can be taken in any district, and, at least at the discovery stage, his expenses in this regard would not be substantially increased. Moreover, a decision by the district court disposing of the principal action on motion would not oust the court of appeals of its jurisdiction; it would merely avoid an unnecessary appellate decision.

More generally, the lower court is allowed to continue its proceedings while interlocutory appeals are being considered. A similar rule should govern 1404(a) orders since the basic consideration justifying appeal in either case is the prevention of irreparable injury. Cf. 6 MOoRe $\llbracket 54.13$, at 135 .

Not all pre-trial activities could be accomplished pending review. Motions requiring the presence of witnesses or parties for whose convenience the transfer was sought would have to be delayed. In addition, time would have to be allowed for the taking of depositions to be used in lieu of the appearance of witnesses who would have testified had the result on appeal been different.

The Federal Rules allow district courts to establish their own procedures for docketing actions on the trial calendar. FED. R. Crv. P. 40. In some districts, an action is automatically docketed when the pleadings are completed. E.g., D. Mass. Rute 11. In others, a motion by a party is required to docket an action. E.g., D. CoNN. RuLE 7. Under either of these rules, a stay would neither require removal of an action already docketed nor prevent docketing when issue is joined. But rules requiring the action to be ready for trial before docketing might require amendment to accommodate 1404(a) cases. E.g., E.D. N.Y. Rule 1(b). In any event, actions transferred after appeal would have to go to the bottom of the docket in the transferee district. 
volving lengthy preliminaries, review would therefore cause virtually no delay. ${ }^{38}$ Indeed, when reversal results in trial in a district with a less crowded docket, review might effect a more expeditious determination. ${ }^{39}$ More important, the possibility of abuse should not jeopardize substantial rights of parties. To the extent place of trial is in fact a matter of major importance, appeal, even if time consuming, should be allowed.

By refusing to regard transfer orders as final and introducing the extraneous issues involved in mandamus, courts have obscured the basic question whether the litigants' interest in the place of trial warrants immediate review. Under current federal practice, appeal as of right is the normal form of first-instance

38. The question here is one of fact: will the appeal be disposed of before all the other pre-trial procedures are complete. While the answer depends greatly on the particular case, the figures below, showing the median time from issue to trial in the district courts of each circuit and the median time from the filing of a notice of appeal to its disposition, indicate that not infrequently the appeal would be determined before the action was ready for trial.

Median time (in months) from issue to trial in the district courts, and from filing of notice of appeal to disposition of the appeal in the courts of appeals, during fiscal year ending June 30,1955 :

\begin{tabular}{cccc}
\hline Circuit & $\begin{array}{c}(1) \\
\text { District Court } \\
\text { from issue } \\
\text { to trial }\end{array}$ & $\begin{array}{c}(2) \\
\text { Circuit Court } \\
\text { from notice } \\
\text { of appeal to } \\
\text { determination }\end{array}$ & $\begin{array}{c}(3) \\
\text { Difference } \\
(2)-(1)\end{array}$ \\
\hline All circuits & $9.1^{*}$ & $9.0^{* *}$ & -0.1 \\
1st & 14.5 & 6.4 & -8.1 \\
2d & 25.4 & 8.0 & -17.4 \\
3d & 21.9 & 6.3 & -15.6 \\
4th & 8.0 & 4.8 & -3.2 \\
5th & 5.9 & 10.0 & +4.1 \\
6th & 8.7 & 11.8 & +3.1 \\
7th & 11.3 & 8.2 & -3.1 \\
Sth & 7.0 & 7.9 & +0.9 \\
9th & 8.0 & 17.2 & +9.2 \\
10th & 6.3 & 8.1. & +1.8 \\
excluding District of Columbia Circuit & \\
*:* including District of Columbia Circuit & & \\
\hline
\end{tabular}

Dir. Adarin. Off. U.S. CTS. Ann. Rep. 159, 182-86 (1955).

39. Length of the trial calendars is one factor that might be considered in determining the convenience of the parties and the interests of justice, even though the court is barred from considering its own convenience. Fannin v. Jones, 229 F.2d 368 (6th Cir.), cert. denticd, 351 U.S. 938 (1956).

If the figures given in note 38 supra are assumed to represent actual times, an action which, after reversal, was transferred from the First Circuit to the Fourth, Fifth, Eighth, Ninth, or Tenth Circuit would come to trial sooner than if the transfer order had not been appealed and reversed. A similar saving would result when an order granting a transfer to a district in the Second or Third Circuit was reversed. Of course, if an order granting a transfer is affirmed, the time consumed by the appeal adds to the total time required to reach a decision on the merits of the case. 
review. ${ }^{40}$ Mandamus is reserved for extraordinary cases, not broad classes of orders. ${ }^{41}$ Arguments might be made for replacing appeal as of right with discretionary review in all cases, or for introducing such review into broad areas of the law. ${ }^{42}$ Changes as fundamental as these should be for Congress to consider and not for the courts to attempt while deciding the narrow issue of 1404(a) review. So viewed, courts refusing mandamus to avoid establishing precedent for general discretionary review appear justified. In any event, since the Cohen definition of finality encompasses 1404(a) orders, the Supreme Court, which must sooner or later resolve the conflict among the circuits, can grant immediate review without altering the structure of the judicial system.

40. 28 U.S.C. $\$ \S 1291,1292$ (1952) (providing appeal as of right from final orders and certain interlocutory orders).

41. Ex parte Fahey, 332 U.S. 258, 259-60 (1947) ; Roche v. Evaporated Milk Ass'n, 319 U.S. 21 (1943); see notes 15, 17 supra. But see 6 MOORE If 54.10[2], at 71-74.

Mandamus has been held to lie for review of any order denying a jury trial. Ex parte Simons, 247 U.S. 231 (1918) ; Goldblatt v. Inch, 203 F.2d 79 (2d Cir. 1953). The basis of this holding is unclear. It may constitute an exception to the extraordinary case theory or embody the concept that jury trial occupies so high a place in the scale of judicial values that any denial is extraordinary.

42. See, e.g., JuD. CoNr. U.S. ANN. ReP. 27 (1953) (recommending amendment of the Judicial Code to allow appeal of otherwise unappealable orders at the discretion of a court of appeals, upon certification by the district judge). 